\title{
The impact of internal factors on the use of technology in higher education in Saudi Arabia during the COVID-19 pandemic
}

\author{
Abdullah Mohammed Al-Ghurbani ${ }^{\text {a,b }}$, Fawaz Jazim ${ }^{\mathrm{a}}$, Mohammed Abdulrab ${ }^{\mathrm{c}}$, \\ Yaser Hasan S. Al-Mamaryc,* and Imran Khan ${ }^{\mathrm{a}}$ \\ ${ }^{a}$ Department of English, College of Arts, University of Ha'il, Hail, Saudi Arabia \\ ${ }^{\mathrm{b}}$ English Department, Faculty of Arts and Humanities, Sana'a University, Sana'a, Yemen \\ ${ }^{\mathrm{c}}$ Department of Management and Information Systems, College of Business Administration, University of Ha'il, \\ Hail, Saudi Arabia
}

Received 5 April 2021

Accepted 11 July 2021

\begin{abstract}
.
BACKGROUND: Technology has recently become a major component of the educational field and learning process for it provides students with opportunities to learn more effectively and to operate efficiently in this age of technological advances. As academics, the use of technology in universities is transforming our work, and more specifically the way we support students in the classroom. As higher education institutions bring more technology into their classrooms, academics will in turn strive to put more technology in their students' hands. That is, if they are prepared to do so. More importantly, ICT (Information and Communication Technology) in this ongoing COVID-19 pandemic becomes a central and integral focus globally regardless one is associated with college or university.

OBJECTIVE: This paper therefore attempts to examine the internal factors that should be taken into consideration when using technology for teaching and learning purposes in higher education in Saudi Arabia.

METHODS: The study develops a number of hypotheses and a theoretical framework based on a questionnaire conducted among the faculty staff in Hail university to test the study hypotheses.

RESULTS: All the study six hypotheses have been supported. The relationship among these hypotheses are clear and significant. Data analysis of this study have shown that perceived usefulness, perceived ease of use, computer self-efficacy, attitudes and computer anxiety have direct and substantial effect on the university teaching staff's intention to use technology. CONCLUSIONS: The findings of this study will for sure assist in overcoming the problems and difficulties facing the use of ICT in higher education in Saudi Arabia, particularly those challenges which have arisen amid the outbreak of the COVID-19 pandemic.
\end{abstract}

Keywords: Information communication technologies, adoption, higher education, Saudi universities, Hail university

\footnotetext{
${ }^{*}$ Corresponding author: Yaser Hasan Salem Al-Mamary, Department of Management and Information Systems, College of Business Administration, University of Ha'il, Ha'il, Saudi Arabia. E-mail: yaser_almamary@yahoo.com.
} 


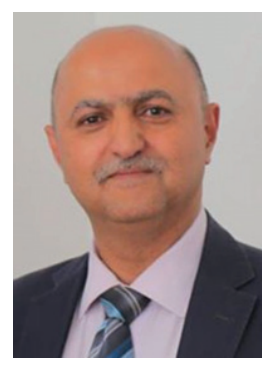

Dr. Abdullah M. Al Ghurbani is currently an assistant professor at the English Department, Faculty of Arts and Humanities, Sana'a University, Yemen. He completed his $\mathrm{PhD}$ in Modern English Literature at Sana'a University in 2015. In 2012, he got the TESOL Certificate from SIT, USA. He got an MSED from SIUC, USA in 2005. Abdullah's work mostly falls under Literature, Translation, TESOL, and Higher Education Administration.

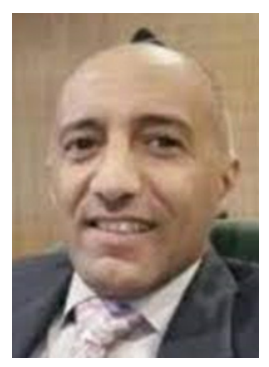

Fawaz Jazim is an Associate Professor of English literature in the Department of English, Sana'a University, Yemen and Hail University, the KSA. He was promoted into the position of Associate Professor in the year 2016 and since then he has been supervising many $\mathrm{MA}$ and $\mathrm{PhD}$ students working on their theses in English literature, comparative literature and translation. Dr. Fawaz's research interest is to explore how literature is a statement of community. Recently, he has developed an interest in exploring the use of technology in higher education particularly amid the outbreak of COVID-19 in the late 2019 and early 2020.

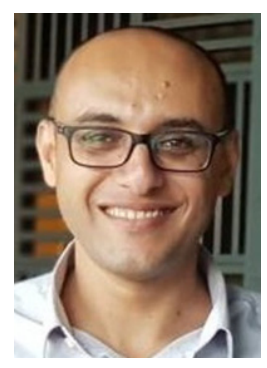

Dr. Mohammed Abdulrab is currently an assistant professor at College of Business Administration, and HR consultant at University of Hail, Saudi Arabia. He completed his PhD in Human Resource Management at Universiti Sains Islam Malaysia (USIM). His areas of interest include HRM, Leadership, Organizational Behavior, Psychological Empowerment, and Entrepreneurship, Abdulrab is well-trained in quantitative analysis using SPSS, AMOS-SEM, and SmartPLS-SEM.

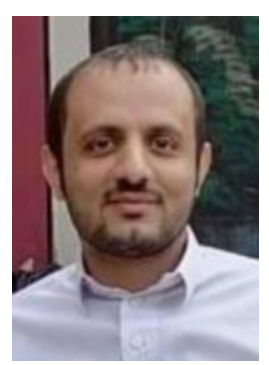

Dr. Yaser Hasan Al-Mamary is currently an assistant professor at College of Business Administration, University of Hail, Saudi Arabia. He completed his $\mathrm{PhD}$ in Technology Management at Universiti Tun Hussein Onn Malaysia (UTHM) in 2015. $\mathrm{He}$ is from Yemen. Yaser's work mostly falls under the umbrella of MIS, Entrepreneurship, Management, Business IT, IS Success, Technology Adoption, Technological Capability, Organizational Commitment, and Educational Technology.

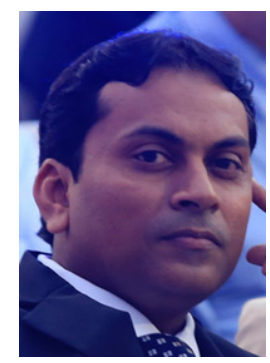

Dr. Imran Khan is an assistant professor at College of Arts, University of Hail, Kingdom of Saudi Arabia. He holds $\mathrm{PhD}$ in English Language Studies from School of Languages Literacies and Translation, University Sains Malaysia, Pulau Pinang. Khan's contributed at both national and international level in reputed journals. $\mathrm{He}$ research interest and contribution includes: Reading performance, job satisfaction, job stress, technology integration, employee creativity, based reading instruction and leader's creativity.

\section{Introduction}

How does the use of information and communication technologies affect higher education? It is observed for the past 3 decades that information and communication technologies (henceforth, ICT) has drastically restructured teaching and learning process in context of higher education $[1,2]$. As a matter of fact, ICT in ongoing pandemic becomes a central and integral focus globally regardless one is associated with college or university. Pajo and Wallace [3] point out that ICT in academia is more noteworthy than earlier due to its growth and demand in education sectors which brings substantial change in teaching and learning process. The question then becomes, are faculty staff in Saudi higher education institutions prepared to use ICT. How can they best plan to incorporate ICT into their classroom? How can they best plan to ensure effective technology integration? How can they be sure that the ICT are support pieces to their instructional practice, rather than a replacement? These are important questions that we need to be able to answer for our own work, but more importantly so that we can continuously strive to be a 21 st century academics for our students. The use of ICT to support instruction in higher education is vital. How we use these technologies is going to make a critical difference in how we measure our students' success and how they are supported to meet 21 st century skill sets. ICT is beneficial for learners since it promotes students centered and self-directed approach. ICT proposes an alternate powerful, yet very useful learning environment for students, consequently, students can engage themselves in a more vigorous and constructive manner so as to meet the challenges $[4,5]$. Therefore, the aim of this study is to 
ascertain the internal factors accountable for teaching in use of ICT. This study investigates what are the internal factors and barriers that faculty staff come across when using ICT. This paper tests a number of hypothesis related to the internal factors on the use of technology among faculty members in Saudi Arabia, investigates the challenges facing the faculty members, and suggests a number of recommendations to improve teaching and learning.

Information Communications Technology has influenced higher education in the 21 st century and its impact in the coming years will grow rapidly and will be one of the main factors of change. Higher education in many countries faces a lot of changes and the use of ICT means more students-centered settings [6]. The rapid changes in technologies led Saudi Arabia to develop its higher education system. More attention has been paid to incorporate ICT to meet the demands of the learners [7]. There is always a need to stimulate faculty staff in universities to change their attitude positively towards the use of ICT [8].

According to Al-Mamary [9], the successful adoption of ICTs in Saudi Arabia can vary in accordance with different factors. Higher education in Saudi Arabia has a high demand [10], so the universities have to adapt the ICT as an effective way to develop teaching and learning. Adapting ICT in Saudi universities would definitely benefit the whole nation. As Saudi universities are facing new levels of competition, integrating ICT will develop the process of teaching and learning. Therefore, understanding the attitudes and the perception of the faculty of Saudi universities towards the use of ICT is vital. Currently the main challenge facing the faculty is how to meet the expectations of their students [11], so the faculty need additional support.

The use of ICT in higher education institutes in Saudi Arabia will help the Saudi Ministry of Higher Education to develop practical applications of ICT. Some researchers indicate that there are some barriers the faculty from using ICT in Saudi universities such as: lack of technology, lack of training, and lack of time [12].

In the light of these data regarding the use of technology to support teaching and academic work in higher education, this study addresses the following research question:

What are the internal factors that influence the teaching staff's use of technology to carry out their teaching and academic duties in higher education institutions in Saudi Arabia during the COVID-19 pandemic?

\section{Literature review}

Technology has dramatically changed the manner people acquire information, carry out studies, and communicate with others globally. This era has eliminated the distance barriers and has made it feasible for higher education institutions to successfully teach all and sundry. Technology integration is being more and more used in training to enhance teaching and studying. This speedy development of era integration has offered higher education a pattern to find new approaches in teaching. This literature review examines the importance of using ICT in higher education in general and its impact on university and college students.

There is a great deal of research and information addressing information communication technology infusion into the higher education classrooms. However, these studies report mixed results of effectiveness, but overall, the trend continues to support an increase in adopting information communication technologies within the higher education classroom environment. Emerging technologies revolutionize the way students and faculty members communicate and interact with each other [13]. The literature indicates that information communication technologies have the potential to facilitate learning in a pedagogical environment [14].

Technology has recently become a major component of the educational field and learning process for it provides students with opportunities to learn more effectively and to operate efficiently in this age of technological advances. More importantly the usefulness of technology for education has become very clear amid the outbreak of the COVID-19. Dawes (2001) for example emphasizes the potentiality of recent technologies to support education and provide effective communication between students and teachers. He also emphasizes the effectiveness of technology in improving the quality of learning as well as teaching. This is true from the perspective of the authors of this paper as they have taught at the college level for years and support the use of ICT in classes. The interaction between the students and the faculty staff becomes very fruitful.

[15] wrote a book about the importance of adopting technology in higher education in Africa. The book consists of novel and empirical research in broad areas of technology and curriculum in selected African countries. The central theme of the book is technology and the higher education curriculum. The book consists of case studies from selected African 
countries, namely, Lesotho; Namibia; Kenya; South Africa; Zimbabwe; Tanzania and Nigeria. These studies confirm that in this contemporary digital era, educational technology is playing an increasingly important role. It has become so ubiquitous and fundamental in the teaching and learning. Higher education sectors across the continent are increasingly compelled to use educational technology to keep up with the needs of 21st-century students who want to be afforded opportunities to be able to learn in real-time, anytime, and on their own terms using opportunities for creative innovation made possible by new information and communication technologies. Saudi Arabia as a leading economic country in the region and the world is aware of these rapid changes and seeks to adopt the latest technology in this regard in its universities and colleges. The authors believe that this research serves this purpose.

Alwan [16] reviewed eight models and theories on individual acceptance of technology. They examined the strengths and weaknesses of these eight models. Those models and theories are TRA, SCT, TAM, TPB, MPCU, MM, C-TAM-TPB, and IDT. They believe that the TAM (Technology Acceptance Model) is the most common technology acceptance model reviewed by previous researchers. It is used to predict use and acceptance of information systems and technology by individual users. In addition, it is one of the most influential models widely used in the studies of the determinant of technology acceptance.

[17] state that TAM 3 emphasizes the unique role and processes related to perceived usefulness and perceived ease of use and theorizes that the determinants of perceived usefulness will not influence perceived ease of use and vice versa. This is an important theoretical contribution by itself because there have been many inconclusive findings regarding the relationships among some of these determinants, perceived usefulness, and perceived ease of use.

Testing Technology Acceptance Model 3 from the authors point of view is intact to the core of this research as it focuses on perceived usefulness and perceived ease of ICT in higher education.

Osika, Palkowski [18] also explain the role technology has played in changing the way instruction is delivered in the universities across the U.S.A. emphasizing that almost "two third of all higher education institutions in the United States offer online courses and/or programs in order to remain competitive with other institutions of higher learning and to fulfill the diverse needs of today's busy students".
Asiri, Asiri [19] also highlight the fact that Saudi universities have started adopting E-learning and its facilities more and more frequently, "a phenomenon which is mainly caused by the steady rise of the Saudi Arabian student population in higher education."

Moreover, a number of studies have highlighted the benefits of the integrating technology in education. For example, Stephens, Hernandez [20] emphasizes how technology enhances the quality of learning. van Braak [21] states that technology equips students with the necessary technological skills that would enable them to be more interactive. Al-Zaidiyeen, Mei [22] explain how technology promotes teachers and students' performance and motivation. So, all these authors support the impact of using technology in higher education and how it improves the quality of teaching and learning. However, this potential of technology may not be easily reached as it is challenged by a number of obstacles. Among these obstacles are, from the perspective of the authors of this research, lack of access to the internet or weak internet connections, the online security threats, and some faculty members are not familiar with the use of ICT in teaching.

A lot of previous studies support the importance of using modern Technology in higher education, for instance, Chuntao [23], and Gleadow, Honeydew [24]. While Gammill [25] discusses the importance of the use of web-based technologies in Higher Education and how it continues to grow. Universities and colleges must take a proactive stance to fulfill the educational needs of society in the twenty first Century. The adoption and use of web-based technologies are the methods that colleges and universities can accept and include to meet the task of educating the students of the 21 Century. Greater use of web- based distance education technology is needed to improve productivity, Gleadow et al (2015) stated that information and communication technologies are rapidly changing and in order to identify new, different or better alternatives, horizon scanning is important, to keep up-to date with how students are interacting with the world academically. We also have a responsibility to make sure that our instruction does not become locked into some early 21 st century method. The manner with which we engage in education needs to match and be continuous with engagement with the rest of the digital world.

Chuntao, D. (2010) also highlighted the importance of modern instructional technology and how it has revolutionized teaching and learning in higher education. It can refine, upgrade, and alter the current 
way we teach in higher education. ICT can provide drill and practice, simulate actual working or emergency conditions in the classroom or outside the classroom. Chuntao, D. developed a model to examine the variables on the decision to use instructional technology. These variables are: the people, the technology, the environment and the others. On the other hand, Balash, F., Yong, Z. \& Bin Abu, B. (2011) state that Universities as a learning organization have had remarkable attention to utilizing state-of-art technologies to facilitate their own progress, particularly in the teaching - learning domain. According to lecturers' narratives integrating educational technological tools in teaching cannot be only confined in lecturers' internal factors such as habits, attitudes, and beliefs. Some factors also are affecting the adoption process externally such as departmental policies and programs, updated and upgraded resources, mentoring, training, rewarding, salary increment, and quality evaluation system.

Regarding the hypothesis that the authors formulated in this research, there are a lot of studies that discuss the relationship between the different factors, among these is Joo, Y. J., Park, S., \& Lim, E. (2018) who discuss the structural relationships between teacher self-efficacy, perceived ease of use, perceived usefulness, and intention to use technology for preservice teachers. They found that Technology Pedagogy and Content Knowledge would significantly affect a teacher's self-efficacy in learning environments with new learning technologies and media. Penny, K. I. (2011) tested some factors that influence e-learning in higher education in UK. Factor 1 can be interpreted as participation in information and communication technologies in connection with university studies and has high loadings for contacting lecturers and students, searching for information in departmental and university web pages, participating in online discussions, and submitting assessments online. Factor 2 represents the usage of general educational tools such as writing up work, preparing presentations, reading, and downloading digital teaching materials. Factor 3 represents the use of more technical or specialized software for drawing or constructing, processing images or videos, using statistical or mathematical software and using a spreadsheet.

In the research paper Integration of ICT in Higher Education Institutions: Challenges and best practice proposals in view of the experience of Makerere University and other organizations, Tusubira and Mulira [26] state that data framework of African Higher Education is ineffectively evolved and unevenly appropriated. The significant difficulties confronted are absence of mindfulness furthermore, attitude, absence of high level responsibility for the advancement in ICT reconciliation, a deliberate technique for ICT usage, cost of transfer speed and effective use of ICT. To determine these difficulties, it is important to characterize very much arranged ICT strategy for effective activation of assets. Notwithstanding these troubles, various Higher Education Institutions in Africa have gained critical ground in building an ICT framework and creating software engineering and other ICT disciplines. Peeraer and Van Petegem [27] throws a mild on elements influencing integration of ICT in teaching practice in teacher schooling institution in higher schooling in Vietnam. The vital elements for a hit implementation of ICT in teaching-gaining knowledge are ICT competencies, self-assurance to apply laptop, infrastructure, and availability in hardware and software programs. They similarly referred to barriers for the usage of ICT like lack of technical support, insufficient expertise, gender and age of a trainer, and shortage of motivation. The writer states that the enthusiastic nature of instructors towards the use of ICT, ICT regulations, budget, educational management, and skill schooling plays a vital role within the integration manner of ICT.

Lopes [28] prepared a model to evaluate the elearning readiness in Porto's Allied Health Sciences Higher Education Institution which highlighted the importance of usage of ICT for medical students and faculties for teaching-learning purpose. Mostert and Quinn [29] have given reflections about usage of ICT in Teaching and Learning on Professional Development of academic Staff in South Africa. They further mentioned that in South Africa, there is a need in professional development for lecturers to use ICT in teaching and learning. Since technology has revolutionized teaching and learning method and academic staff members face the challenge of introducing effective ways of engaging technology. In the paper ICT in Indian Universities and Colleges, Neeru [30] indicates transformation of higher education in the country in terms of access, equity and quality due to usage of ICT in education. In this regard the opportunities and challenges posed by integration of ICTs in various aspects of higher education in the present scenario are discussed. Also the factors regarding future development in ICT in education sector are also highlighted.

Shabaya [31] highlights the changing role of ICT for delivery of instructions in universities in Kenya. 
Research has shown that ICT explore and simulate abstract concepts while encouraging self-learning, ability to deal with complex problems, encouraging team work and permit for critical thinking. The Author also highlighted the factors on the changing trends in usage of ICT for instruction in higher education universities and colleges. Lopes [28] prepared a model to evaluate the e-learning readiness in Porto's Allied Health Sciences Higher Education Institution which highlighted the importance of usage of ICT for medical students and faculties for teaching-learning purpose.

Qudais, Al-Adhaileh [32] identified the main factors which affect the attitudes of senior faculty members in Jordanian Universities towards using ICT in their teaching activities. Factors identified are lack of motivation to use ICT in teaching - learning purpose, lack of technical skills, insufficient availability of hardware and software, inadequate infrastructure etc. and it is necessary to remove these barriers. They further stated that to succeed utilizing technology in a pedagogically meaningful way, there must be reorganizations in different levels like individual actions, attitudes and at pedagogical levels.

The authors of this research believe that the internal factors on the use of ICT have not been examined in higher education institutions in Saudi Arabia. The factors mentioned in previous literature will definitely help the authors of this research to formulate the hypothesis and examine their validity.

Nawaz and Kundi [33] highlights demographic implications for the user-perceptions of e-learning in higher education Institutions in Pakistan. The factors highlighted are age, gender, qualification, perceptions, experience and organizational characteristics which play an important part in implementation of ICT in teaching-learning purpose.

Bala, Venkatesh [17] believes that information and communication technology (ICT) is a necessary part of the cutting-edge world. In fact, lifestyle and society must be adjusted to satisfy the demanding situations of the current age. ICT is a pressure that has changed many factors of people's methods of life. Considering such fields as medicine, tourism, travel, business, law, banking, engineering and architecture, the effect of ICT in the past has been enormous.

In the paper, Application of ICT in Teaching and Learning at University Level: The Case of Shahid Beheshti University, Vajargah, Jahani [34] the authors highlighted the importance of ICT support in teaching, learning and research activities in higher education. This research is concentrated on the obstacles, facilitators, and the risks of using these technologies in teaching and learning in higher education. In the paper Developing E. learning materials for the software development course, Shi [35] highlights the project work related to the factors on the development of E. learning materials for software development course. The project intended to provide a learning context in which learners can reflect on new material, discuss their tentative understandings with others, actively search for new information, develop skills in communication and collaboration, and build conceptual connections to their existing knowledge base.

In the paper ICT use by Journalism Professor in Colombia Said [36] examines the usage of ICT by journalism professors at Colombian universities. Factors that influence the teaching are uses of ICT and the implementation of pedagogical strategies in the classroom. To support ICT in teaching, pedagogical model is implemented related to new teaching-learning opportunities in the classrooms at Colombian universities.

On the other hand, there have been many studies that have tackled the issue from a broader perspective. In an attempt to promote and encourage the use of technology in education, these studies investigate the factors that influence the use of technology in education in different context. These studies have come up with several factors that impact the use of technology in education. Agbo [37] concludes that there are five major factors that influence the use technology in teaching and learning computer studies in Nigeria, some of which are level of accessibility and ICT training to teachers. Asiri, Asiri [19] refer to several factors that should be taken into consideration when using technology for teaching and learning purposes.

The technological environment in higher education institutions is becoming increasingly challenging and creates new opportunities for the academic staff. Since the introduction of the internet, universities around the world and particularly in Saudi Arabia have witnessed a persistent evolution in technologies and how they are used in the process of teaching and learning. De Freitas and Conole [38] suggest five large technological developments which are in all likelihood to have a great effect on education: a shift towards networked technologies, the emergence of context and location-conscious devices, the increasing number of rich and numerous unique sorts of representations and stimulatory environments possible, a trend in the direction of extracellular and 
adaptive devices, and technological infrastructure that is globally distributed and interoperable.

Wee and Zaitun [39] presented the barriers closer to the use of ICT equipment in coaching and studying of facts systems in Malaysian Universities. The maximum large barriers are rapid change in ICT equipment, greater effort and time needed to integrate ICT equipment in coaching, negative network connectivity, flawed evaluation in integration of ICT tools in teaching and many others. They similarly said that it is necessary to eliminate these barriers for successful implementation of ICT in universities.

Balanskat, Blamire [40] explain that though technology is highly regarded by teachers, obstacles are encountered during the process of adopting the technological facilities. As a result, several studies have investigated the barriers and difficulties that hinder the use of technology in education in different contexts such as Richardson [41], Alonso, Plaza [42], and Alenezi [43]. Al Mulhim [12] studied the Barriers to the Use of ICT in Teaching in Saudi Arabia and found that a number of factors hinder the use of technology in teaching in Saudi Arabia including: lack of access to technology, lack of training, and lack of time. In this regard, higher education institutions can cooperate with the private sector to transfer knowledge. Linzalone, Schiuma [44] states the effect of connecting the universities with the companies to transfer knowledge. The private sector can provide higher education institutions with technology and training.

Regarding the use of technology in Saudi universities, Alharbi, Alshammari [45] stated how online learning developed rapidly and how it contributed to the advancement of research and learning. They particularly focused on the use of mobile technology which provides a novel style of learning. According to Al-Maliki and Mohammed [46], Saudi Arabia is recently investing to adopt Information Communication Technology in educational institutions at all levels. He believes that the impact of this technology will affect all the sectors in Saudi Arabia and has a strategic influence. If the universities focus on improving the quality of teaching and learning through the use of ICT, that will also help the market which will receive the graduates who will share the knowledge they got in universities or colleges in the marketplace. By implementing modern technologies in higher education institutions, we are contributing to improving the society. Linzalone, Schiuma [44] believes that it is important to enhance the standards of higher education institutions by sharing the knowledge among the stakeholders.
Alkhalaf, Drew [47], stated that the impact of Elearning in Saudi Arabia has not received that much attention, particularly on higher education and on academic staff and this issue lacks some contribution. Through the study that they conducted they found that E-learning systems have positive impact in top universities in Saudi Arabia. Basri, Alandejani [48] investigate the adoption of information communication technologies in some Saudi Universities and its impact on the academic performance of the students. The study found that ICT provides support for Saudi University students and improves their academic performance.

The literature reviewed above indicates the importance of using ICT in higher education institutions and the factors influencing this use. They also highlight the impact of using ICT on the faculty staff and the students. To achieve success in any higher education institution ICT should be implemented as it is considered one of the most important elements to improve the quality of teaching and learning. ICT is intimately connected with the best practices of teaching and learning. The literature also helped the authors to formulate the different hypothesis and the impact of internal factors on the use of technology.

\section{Conceptual model}

Based on the above literature, this study develops a research model that is used to assess the important factors that affect the successful use of technology of the teaching staff in the KSA to carry out their academic and teaching duties. Six factors are examined in this paper, five of which are independent variables (perceived usefulness, perceived ease of use, attitudes, self-efficacy, and computer anxiety), one mediating variable (intention) and one dependent variable (the successful use of technology). The proposed model is illustrated in Fig. 1.

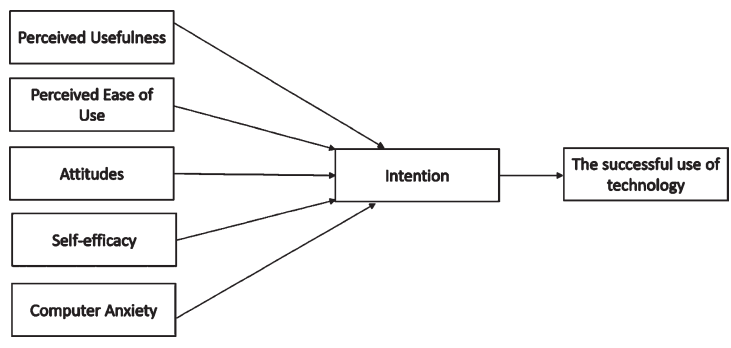

Fig. 1. Conceptual Model. 
Figure (1) above explains the key variables and the main relationship that exists among them. It shows how the dependent variable (the successful use of technology) mediated by the (intention) is presented as the primary construct. Moreover, the independent variables are proposed as key drivers of the intention to technology use. Finally, one key variable is hypothesized to be a mediating variable between the independent variables and dependent variable. All these factors are viewed as internal factors and/ or user-related factors that influence the successful use and integration of technology in Hai'l University, KSA. According to Zhao, Pugh [49], the factors that influence the successful use of technology for learning and teaching purposes are classified into three categories: innovator, innovation and context. The first refers to the factors related to the user; the second are the technology-related factors; the third are the factors inside the learning environment.

This paper focusses on the factors of the first category, the user- related factors. These are the factors that are associated with the teaching staff of any higher education institution, Hai'l University in particular. This is because of the belief that the user is the key element in the process of integrating and using technology in learning and teaching in the academic sphere. Many studies have emphasized this crucial role of users in this process [50-52]. Almalki and Williams [52] state that teacher/ user-related factors are very essential predictor for a successful technology use. They add that teachers are "critical key to successful adoption of ICT .... and [they] should be at the centre of ICT adoption projects". Marcinkiewicz (as cited in Sang, Valcke [53]) also emphasizes that the achievement of a full integration of ICT in education is impossible unless the teacherrelated issues with regard to technology use are given a particular attention.

\section{Hypotheses development}

The researchers have drawn on existing evidence from papers and journal articles to identify and surface the internal factors, experiences, and challenges regarding the use of ICT in higher education in Saudi Arabia. The researchers developed six hypotheses related to the use of technology, and to examine these hypotheses the researchers designed a questionnaire of eight sections focusing on the internal factors.

Hypotheses postulated for this study were as follows:

\subsection{Perceived usefulness}

The term has been originally used by Davis, Bagozzi [54] representing one substantial variable in his model named TAM that influences the behavioral intention to use and adopt technology. The term is defined as "the prospective user's subjective probability that using a specific application system will increase his or her performance within the organizational context" [55]. However, for the purpose of this study, the term is used to mean the degree to which an educational technological item is viewed as useful in teaching, learning and carrying out academic work.

Several studies have emphasized that this construct influences teachers' intention to use technology [15, 54, 56-59]. For example, in the light of their case analysis, Meda and Makura [15] indicate that PU has emerged as a salient factor that affects teacher's intention and decision to use and integrate technology. Moreover, Lu and Viehland [59] have come to the conclusion that PU has "a positive effect on the user's behavior to adopt mobile learning" with $84 \%$ of the participant supporting their hypothesis. In addition, Joo, Park [60] in their discussion of the factors influencing teachers' intention to use technology in three Korean universities, have found that PU has a positive influence on the teachers' intention to use technology emphasizing that the level of intention to use and integrate technology is determined by the level of teachers' PU of technology. Al-Khaldi and Al-Jabri [61] have also come to the same conclusion indicating that technology perceived usefulness has an essential relationship with its behavioral intention and user's utilization. Therefore this study proposes the following hypothesis for examination:

Hypothesis 1: Perceived Usefulness has strong influence on the teaching staff intention to use technology in teaching and learning in technology usage in Saudi higher education institutions.

\subsection{Perceived ease of use}

This is another medicating factor that influences the user's intention to successfully integrate and use technology in a technology-driven context. The term is defined by Davis [55] as "the degree to which the prospective user expects the target system to be free of effort" (PP). The significance and positive relationship between user's perceived ease of use and his intention to use and integrate technology has been confirmed by many studies. Davis [55] and Davis, 
Bagozzi [54] emphasized that like perceived usefulness, PEOU is a predecessor that affects behavioral intention to use technology. Moreover, Alshmrany and Wilkinson [62] found a moderately strong relationship between perceived ease of use and Saudi teachers' behavioral intention to use technology. In addition, Thompson, Higgins [63] found PEOU to be an important determinant of the behavioral intention to use technology. The same is also indicated by Chin and Gopal [64] who emphasized the direct influence of PEOU on behavioral intention to utilize technology. Therefore, this study proposes the following hypothesis to test its validity and significance:

Hypothesis 2: Perceived Ease of Use has a strong influence on the teaching staff's intention to use technology in teaching and learning in technology usage in Saudi higher education institutions.

\subsection{Attitudes}

The term is defined by Gibson, Ivancevich [65] as "a positive or negative feeling or mental state of readiness, learned and organized through experience, that exerts specific influence on a person's response to people, object and situation" (P. 70). Attitude includes three important components. These components according to Triandis, Malpass [66] are the affective component which stands for the emotional response or feeling aspect; the second is the cognitive domain of attitude which reflects the individual's beliefs about computers and/ or technology; the last component is the behavioral part of attitude which is concerned with what an individual intends to do. Rogers, Singhal [67] emphasized that a person's attitudes towards a new technology are essential to its diffusion. According to Watson [68], teachers' positive attitudes towards technology help teachers to both increase their computer utilization and avoid resistance to computer use. Isleem [69] emphasized that teachers' attitudes are essential prerequisite for the integration of new technology in classroom. Albirini [70] states that teachers with less technological capabilities are often encouraged by positive attitudes leading them to "learn the skills necessary for the implementation of technology-based activities in classroom" (P. 376). MacCallum [71] also found attitudes to be an important factor influencing teachers' intention to use technology. The same is also emphasized by many other [72-74]. In the light of this, the following hypothesis is formulated:

Hypothesis 3: There is a significant relationship between attitudes and the teaching staff's intention to use technology in teaching and learning in technology usage in Saudi higher education institutions.

\subsection{Self-efficacy}

Bandura [75] defines self-efficacy as the "beliefs in one's capabilities to organize and execute the courses of action required managing prospective situations." Computer self-efficacy is defined as the individual's perception about his/ her ability to use technology in several contexts/ situations [76]. A plethora of research on self-efficacy has clearly shown the determinative relationship between teacher self-efficacy and the intention to use technology [53, 58, 77-81]. For example, Anderson, Groulx [79] found that teachers' self-efficacy is a determining factor that influences their intention to use technology. Ball and Levy [81] clearly demonstrated that of all the variables they investigated computer self-efficacy was the only significant predictor that influenced instructors' intention to use technology in classroom. Moreover, several studies indicated that low self-efficacy influences teachers' intentions to use technology in teaching and learning [82-84]. The following hypothesis is thus formulated:

Hypothesis 4: Self-efficacy is positively related to the teaching staff's intention to use technology in teaching and learning in technology usage in Saudi higher education institutions.

\subsection{Computer anxiety}

The term refers to "the fear or apprehension felt by individuals when they use computers or when they consider the possibility of computer utilization" [81]. According to Thatcher and Perrewe [76], it stands for the user's fears of the consequences of his use of technology such as losing data or committing major mistakes. Anxiety has always been viewed as an important variable influencing the technology use and adoption [85, 86]. According to Harrington, McElroy [87] computer anxiety results in stress and influences performance leading user to decide to avoid technology usage. The same idea is also emphasized by many researches [88-90]. These studies as cited by Awofala, Olabiyi [91] showed that computer anxiety increases struggle with technology and represents a barrier to a person's intention to use technology and his adoption of it. On the basis of this available literature, this study examines the following hypothesis:

Hypothesis 5: There is a significant relationship between computer anxiety and the teaching staff's 
intention to use technology in teaching and learning process in Saudi higher education institutions.

\subsection{Intention}

Behavioral intention refers to a person's likelihood to take part in a specific behavior [92]. It usually tells whether a person is committed enough to perform a certain behavior or not [93]. In this study, the term is used to mean the teacher's behavioral intention to adopt and use technology in the process of teaching and learning. Several studies have emphasized that behavioral intention positively influences the use and adoption of technology [62, 92, 94, 95]. In Saudi Arabia, studying the factors influencing the adoption of ICT by Saudi teachers, Alshmrany and Wilkinson [62] found a moderate positive relationship between behavioral intention and the technology actual use. In Kuwait also, Aljazzaf [94] confirmed that behavioral intention factor had an affective influence on the use of multimedia technologies by the English language teachers. Yakubu and Dasuki [92] in their study on the factors influencing the adoption of e-learning technologies in higher education in Nigeria concluded that behavioral intention was an essential determinant of technology actual usage in the Nigerian higher education institutions. Therefore, the following hypothesis is formulated in this study:

Hypothesis 6: Behavioral intention has a significant positive influence on the teaching staff's technology usage in Saudi higher education institutions.

\section{Methodology}

\subsection{Research design}

Creswell (as cited in Lu and Viehland [59]) indicates that the quantitative approach is used in studies in which attitude is measured. Therefore, in this study, the quantitative approach is used to examine seven factors that are assumed to influence the educational and academic use of technology by the teaching staff. In addition, the study used a mixed-mode surveys [96]. The questionnaires were developed with the use of an online survey and paper-based survey, which was carried out in the offices of the respondents.

\subsection{Research instrument}

For the verification and validation of the proposed model above and testing the research hypotheses, a measurement instrument was developed and adopted from the available literature addressing the different aspects of the six sections (see Table 1). A five-point Likert scale ranging from (strongly agree) to (strongly disagree) is used. The questionnaire includes 35 questions for the research participants:

\subsection{Sample and data collection}

The study was conducted among teaching staff at Hail University where they have the same working environment as the teaching staff in Higher education in Saudi Arabia. As far this study is concerned

Table 1

Questionnaire Sources

\begin{tabular}{llc}
\hline Section & Sample Question & No of Items \\
\hline Perceived Usefulness & Using technology would make it easier to do & 6 \\
Perceived Ease of Use & my academic and teaching duties. & 6 \\
& I would find technology to be flexible to & interact with. \\
Self-efficacy & I could complete my teaching and academic & 4 \\
& job using technology if someone showed & me how to do it first. \\
Attitudes & I like working with technology. \\
Computer Anxiety & The challenge of learning about technology \\
& is exciting. \\
Intention & I plan to use technology in my teaching and \\
The successful use of & academic job frequently. \\
technology & Using technology can help regulate my \\
& teaching and academic work processes and \\
\end{tabular}


however, multi-mode surveys were used. This type of survey requires the collection of data from the respondents using more than one type of survey strategy and combines them for analysis [96]. The questionnaires have been distributed to teaching staff at Hail University. However, the response rate was insufficient. Thus, the authors chosen to expand the sample to increase access to participants, data was collected via online survey using non-list-based random sampling which allow for the selection of a probability-based sample without the need to actually enumerate a sampling frame [97]. Moreover, a total of 380 valid surveys were considered for SPSS and PLS data analysis. The population doesn't include the non-teaching faculty members like the university administrative staff or the university students. Table (2) below shows the demographic distribution of the sample population (colleges, age, ranks, sex, etc.)

\section{Findings}

\subsection{Descriptive analysis}

Table 2 shows demographic information about the participants. The majority of the respondents were male $60.0 \%$ and $40.0 \%$ was female. In terms of age, most of the respondents are in the age group between 40 and 44 years old $37.4 \%$, and $25.0 \%$ of total respondents are between 30 and 34 , while $24.7 \%$ of them are in the age group of 35 to 39 years, and $0.8 \%$ of total respondents are in the age group of 25 and 29 years old. In term of academic rank, assistant professor is the largest group with $54.0 \%$ followed by Lecturer $25.0 \%$, associate professor $14.7 \%$ and professor $6.3 \%$.

\subsection{Measurement model assessment}

To assess convergent reliability, factor loadings, composite reliability (CR) and average variance extracted (AVE) were examined [9, 98-105] As specified in Table 2, items' loadings were in the acceptable ranges (0.695and 0.961) [98]. Furthermore, the composite reliability of constructs was above the threshold value of 0.7 [106], Consequently, there are no issues pertaining to internal consistency. Finally, The AVE values for construction met the minimum score of 0.5 [98] and convergent reliability was thus developed. In addition, discriminant validity was evaluated using the HTMT test [107]. Henseler, Ringle [107] indicated that HTMT values could be a
Table 2

Participants' demographics

\begin{tabular}{|c|c|c|c|}
\hline Measure & Items & Frequency & Percentage \\
\hline \multirow[t]{2}{*}{ Gender } & Male & 228 & $60.0 \%$ \\
\hline & Female & 152 & $40.0 \%$ \\
\hline \multirow[t]{5}{*}{ Age } & $25-29$ years old & 3 & $0.8 \%$ \\
\hline & $30-34$ years old & 95 & $25.0 \%$ \\
\hline & $35-39$ years old & 94 & $24.7 \%$ \\
\hline & $40-44$ years old & 142 & $37.4 \%$ \\
\hline & 45- above years old & 46 & $12.1 \%$ \\
\hline \multirow[t]{16}{*}{ College } & $\begin{array}{l}\text { College of Applied } \\
\text { Medical Sciences }\end{array}$ & 31 & $8.2 \%$ \\
\hline & $\begin{array}{l}\text { College of Arts } \\
\text { and Sciences }\end{array}$ & 27 & $7.1 \%$ \\
\hline & College of Business & 33 & $8.7 \%$ \\
\hline & Administration & & \\
\hline & College of Community & 25 & $6.6 \%$ \\
\hline & $\begin{array}{l}\text { College of Computer } \\
\text { Science and } \\
\text { Engineering }\end{array}$ & 23 & $6.1 \%$ \\
\hline & College of Dentistry & 21 & $5.5 \%$ \\
\hline & College of Education & 32 & $8.4 \%$ \\
\hline & College of Engineering & 35 & $9.2 \%$ \\
\hline & College of Medicine & 27 & $7.1 \%$ \\
\hline & College of Nursing & 23 & $6.1 \%$ \\
\hline & College of Pharmacy & 25 & $6.5 \%$ \\
\hline & $\begin{array}{l}\text { College of } \\
\text { Preparatory Year }\end{array}$ & 16 & $4.2 \%$ \\
\hline & College of Public Health & 20 & $5.3 \%$ \\
\hline & College of Sciences & 25 & $6.5 \%$ \\
\hline & College of Shariah-Law & 17 & $4.5 \%$ \\
\hline \multirow{5}{*}{$\begin{array}{l}\text { Academic } \\
\text { Rank }\end{array}$} & Lecturer & 95 & $25 \%$ \\
\hline & & & \\
\hline & Assistant Professor & 205 & $54 \%$ \\
\hline & Associate Professor & 56 & $14.7 \%$ \\
\hline & Professor & 24 & $6.3 \%$ \\
\hline
\end{tabular}

problem if values exceed 0.85 . Discriminant validity was established as all the estimates in Table 3 were below the critical value of 0.85 .

\subsection{Structural model assessment}

The bootstrapping test in Smart PLS was used to test the structural model. The t-statistic and the associated $p$-values were used to test each of the paths and their associated hypotheses. As seen in Fig. 4 and Table 4, the structural model evaluation gives an indication of the hypothesis tests, with six direct hypotheses. The results indicated that all hypotheses were supported. H1 ( $\beta=0.157, t=2.647$, 


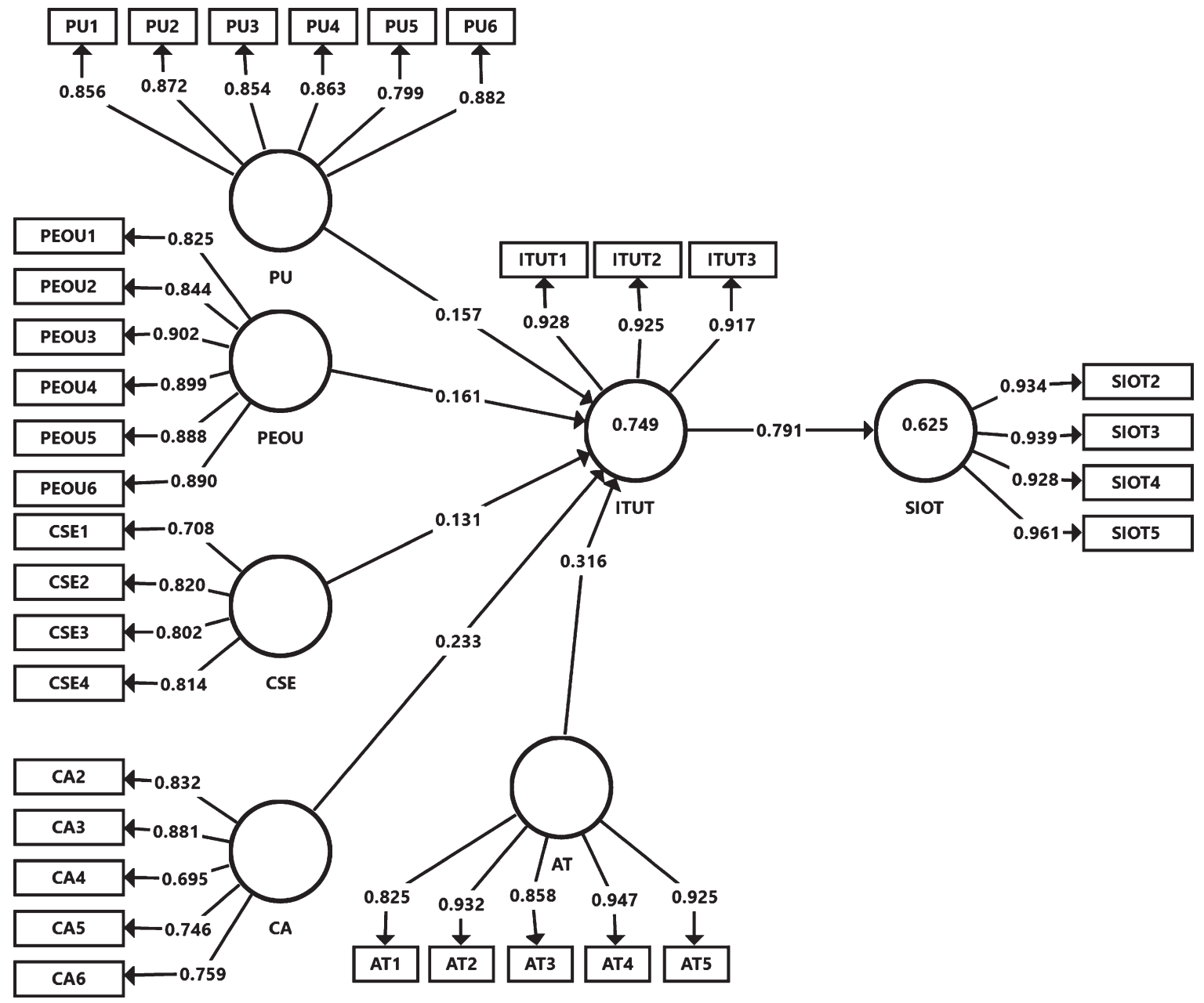

Fig. 2. Structural Model. Key: PU: perceived usefulness, PEOU: Perceived Ease of Use, CSE: computer self-efficacy, CA: computer anxiety, AT: attitude, ITUT: intention to use technology, SIOT: successful implementation of technology.

Table 3

HTMT results

\begin{tabular}{lccccccc}
\hline & AT & CA & CSE & ITUT & PEOU & PU & SIOT \\
\hline AT & & & & & & & \\
CA & 0.768 & & & & & & \\
CSE & 0.651 & 0.735 & & & & & \\
ITUT & 0.844 & 0.840 & 0.752 & & & & \\
PEOU & 0.752 & 0.819 & 0.748 & 0.815 & & & \\
PU & 0.807 & 0.715 & 0.647 & 0.796 & 0.807 & & \\
SIOT & 0.649 & 0.650 & 0.637 & 0.845 & 0.670 & 0.644 & \\
\hline
\end{tabular}

HTMT: Heterotrait-monotrait ratio.

$p<0.05), \mathrm{H} 2(\beta=0.161, t=3.318, p<0.05), \mathrm{H} 3$ $(\beta=0.131, t=3.402, p<0.05), \mathrm{H} 4 \quad(\beta=0.233, t=$ 4.513, $p<0.05), \mathrm{H} 5(\beta=0.316, t=5.149, p<0.05)$, and H6 $(\beta=0.791, t=34.202, \quad p<0.05)$, were supported. Moreover, in terms of the rule of thumb for acceptable $\mathrm{R}^{2}$ varies, according to Cohen [108], the $\mathrm{R}^{2}$ value of 0.26 and above is considered substantial. As presented in Figure 00, it can be seen that all the independents variables explain $74.9 \%$ of the variance in intention to use technology. Further, intention to use technology explain $62.5 \%$ of the variance in successful implementation of technology.

\section{Discussion}

The present study is designed to identify the significant internal factors that influence the technology use and integration by the teaching staff at the Saudi 
Table 4

Structural assessment results

\begin{tabular}{lccccr}
\hline Hypothesis & Relationship & Std. Beta & t-value & $p$-value & Decision \\
\hline H1 & PU -> ITUT & 0.157 & 2.647 & 0.008 & Accepted \\
H2 & PEOU -> ITUT & 0.161 & 3.318 & 0.001 & Accepted \\
H3 & CSE -> ITUT & 0.131 & 3.402 & 0.001 & Accepted \\
H4 & CA - ITUT & 0.233 & 4.513 & 0.000 & Accepted \\
H5 & AT -> ITUT & 0.316 & 5.149 & 0.000 & Accepted \\
H6 & ITUT -> SIOT & 0.791 & 34.202 & 0.000 & Accepted \\
\hline
\end{tabular}

Key: PU: perceived usefulness, PEOU: Perceived Ease of Use, CSE: computer self-efficacy, CA: computer anxiety, AT: attitude, ITUT: intention to use technology, SIOT: successful implementation of technology.

higher education institutions. To achieve this end, a theoretical model was developed. A number of wellknown and well-established theories and models have assisted in the construct of this model. These theories include TAM, TAM3, UTAUT and Delone and Mclean models.

Based on this proposed model, it is hypothesized that perceived usefulness, perceived ease of use, self-efficacy, computer anxiety, and attitudes are significantly related to teaching staff's behavioral intention to use technology which is positively related to the teaching staff's successful use of technology in their teaching and academic work.

As it is clear from table (1), all the research hypotheses are well accepted and supported. The research results and the findings have confirmed that the proposed factors are real determinant of the successful use of technology. In this section, each of the factors is discussed in the light of the survey questionnaire results and some insights from the literature available.

The teaching staff's intention to integrate and adopt technology is strongly determined by how they perceive the usefulness of technology to carry out their learning and teaching duties. If they feel that the use of technology is useful and offers relative advantages allowing them for example to improve the quality of their teaching and academic activities, it is likely that they adopt and integrate technology in their academic and teaching work. This indeed has been supported by the results of this study. Perceived usefulness is found to directly affect the teaching staff's intention to use technology. This finding broadly supports the work of other studies in this regard linking perceived usefulness with the user's intention to integrate technology. For example, the results in this study reflect those of Joo, Park [60] who also found that perceived usefulness has a positive influence on teacher's intention to use technology. This finding was also reported by Kim, Lee [109];Hamid, Razak [110]; and Hussain, Mkpojiogu [111]).

This result may be attributed to teaching staff's belief in the advantages and benefits of technology in carrying out academic and teaching activities and in how technology improves their job performance, productivity and effectiveness. This idea has been supported and confirmed by many previous studies $[15,61,112]$.

Perceived ease of use should be viewed as a crucial determinant of the variance in intention to the use of technology in the workplace generally and in the academic and educational field in particular. In this study, perceived ease of use is found to have a direct and influence on the teaching staff's intention to use technology in their workplace. The earliest supporting evidence for this finding came from several studies [54, 64, 113, 114]. This finding is also consistent with many recent studies which showed that perceived ease of use dis predict the intention to using and adopting technology $[60,72,112,115,116]$.

This result which is in support of the developed hypothesized relationship between perceived ease of use and behavioral intention may be attributed to, as proposed by $\mathrm{Hu}$, Clark [117], the idea that university professors, though of varying technological abilities, are capable of learning new technologies more quickly and with less/ no training chances than other employees in the other business settings. This also can be supported by what Agarwal and Prasad [118] refer to as the level of education and how it is positively connected with ease of use.

Professors' and instructors' attitudes towards technology use in classroom has always been extensively studied as an essential factor for their intention to use technology on the one hand and for a successful integration of technology on the other hand. The result of this study is found to support the developed hypothesized relationship between attitudes and 
the intention to integrate technology at the university level. The findings in this study suggest that participants have positive attitudes towards technology which strengthen their intention to use and adopt technology in their workplace. These attitudes are evident within the three domains (the affective, cognitive and behavioral).

This result is consistent with those of MacCallum [71] which also emphasized the strong relationship between teachers' positive attitudes and their intention to adopt mobile learning. The result in this study is also in agreement with $\mathrm{Lu}$ and Viehland [59] findings which showed that respondents' attitudes were positively related to their behavioral intention to use and adopt mobile learning in New Zealand universities. It also corroborate the results of Teo, Lee [57] that showed that attitudes have direct influence on behavioral intention to use ICT.

It seems possible that this result is due to the idea that the study participants believe that there is a strong relationship between technology and effective teaching at the university and that technology could help offer creative reaching and academic work. The result can also be attributes to the participants' belief in technology as a useful and possible educational tool that would help them improve the quality of their work. Such explanations are supported by several studies such as [52, 70].

Teaching staff's actions, goals, performance and intention to act always vary depending on their view of their self-efficacy. If they have strong belief in their technology strength and abilities, it is most likely that they will have strong intention to use and integrate technology in their teaching and academic work. This is interestingly noted in this study. The finding of this study indicates that self-efficacy does predict the teaching staff's intention to use technology in Saudi higher education institutions. In accordance with the present result, previous studies demonstrated the same [57, 59, 60, 79, 81, 119]. Ball and Levy [81] found computer self-efficacy to be the only significant factor that directly influence instructors' intention to use technology. Similarly, Anderson, Groulx [79] emphasized in their findings that selfefficacy significantly contribute to the prediction of intention to use technology. The result of this study also corroborates the results of Joo, Park [60] which found self-efficacy to have a positive influence on the instructors' intention to use technology. The result also reflects that Lu and Viehland [59] who also found that self-efficacy scored highest among other factors influencing user's intention to adopt mobile learning.
It also reflects that of Awofala, Olabiyi [91] who indicated that self-efficacy positively correlated with teachers' behavioral intention to use ICT.

Given this direct effect of self-efficacy on teaching staff's behavioral intention to use technology, a possible explanation for this result might be that when they have an approving judgement of their strength and skills with regards to technology, they are most likely to be inclined to use technology in carrying out their teaching and academic duties.

Computer anxiety has recently become a major addition to the array of other anxiety types including 'test anxiety' and 'math anxiety' [120] and its importance to and influence on technology use and behavioral intention to use technology has been examined by many recent studies. In this study, given the direct and significant influence of computer anxiety on behavioral intention, the study result shows that there is a significant and direct relationship between them. This result however is contrary to previous studies which suggested that computer anxiety had not a direct and significant influence on instructors' intention to use technology. For example, Ball and Levy [81] found that computer anxiety was not an essential predictors of behavioral intention. There are studies as quoted in Ball and Levy [81] that emphasized that computer anxiety "generally acts as an antecedent to and a moderator of other variables rather than having a direct influence" [14, 121-123]. The same was also emphasized in a study by Mac Callum and Jeffrey [72] which confirmed that ICT anxiety had a mediating impact on the lecturers' behavioral intention to implement mobile learning.

The result of this study nevertheless substantiates some earlier research results like that of Alenezi [43] which confirmed that ICT anxiety had a direct impact on the students' intention to use e-learning in Saudi Arabian governmental universities.

This direct and significant influence of computer anxiety on the teaching staff's intention as seen in this study could be attributed to their academic and technology background in which computers and technology have become an integral part of their professional life. Teaching staff in Saudi higher education institutions don't fear that the use of technology may have a negative consequence. They never feel threatened or overwhelmed when using technology at their workplace. Using and learning about technology is exciting for them. Therefore, anxiety won't be a barrier to their intention to adopt and integrate technology at Saudi higher education institutions. 
Representing a crucial difference between TAM model and TRA model, behavioral intention, according to Tarhini, Hone [95], is a direct and critical antecedent of usage and clearly indicates that the user is prepared to carry out a certain behavior. In conformity with this, the result of this study is found to support the developed hypothesized relationship between the teaching staff's behavioral intention and their technology actual use in Saudi higher education institutions. The finding suggests that behavioral intention is a major factor that causes the teaching staff's actual use of technology.

This finding broadly supports the work of other studies in this area linking behavioral intention with actual use and adoption of technology $[62,71,92,94$, 95]. In accordance with the present result, the studies mentioned above demonstrated that behavioral intention had a positive and significant influence on teachers' actual use and adoption of technology. This results also reflects that of Venkatesh, Morris [56] who also found a direct effect of behavioral intention on the ICT usage.

A possible explanation for this might be the teaching staff's belief that they acquire the knowledge and resources needed to their use of technology in teaching and academic work which indeed positively translates their intention into actual usage, a fact that is clearly illustrated by the substantially high value of the teaching staff's actual use reaching (0.625).

\section{Research implications}

\subsection{Theoretical implications}

It should be notes that this study has significant theoretical implications in the area technology adoption in higher education. The conceptual model this study developed is based on a number popular and reputable theories and models, namely: TAM, UTAUT and TAM 3. The study results clearly supports the relationships these theories proposed and emphasized. This study contributes to the analysis of these theories that are considered to provide groundwork for the research in the field of technology adoption. The study shows how these theories and models can interact and mould to create new relations, interrelations and correlations and thus help better understand the phenomenon of technology adoption and integration in education, higher education in particular.
Moreover, this study attempted to develop a model of technology adoption and integration that considers the user-related factors to explain the use of technology in teaching and academic work. The factors studies in the study proposed model contributed a lot to understand and explain the use of technology in the academic contexts during the COVID-19 pandemic. The results of this study thus provide insightful addition and essential support to the existing literature in the area of technology use in higher education.

\subsection{Practical implications}

At the practical level, the study contributes to the existing literature available on technology integration in many ways. This study has developed a predictive model using the constructs of perceived usefulness, perceived ease of use, computer selfefficacy, attitudes, and computer anxiety to examine the probability of Hail University professors' and instructors' intention to use educational technology in classrooms and academic work. So one implication it succeeded to make is that it has investigated factors that are well-known in the literature of ICT use in education but which were not examines in an emerging context, Hail University being an emerging university in the KSA.

Moreover, this study provides key information to the management of Saudi higher education institutions with regard to the significant use-related factors that predict intention to use technology by the university teaching staff. This information can be used to increase intention and adoption of technology under investigation. Saudi higher education institutions also should take the necessary actions that would increase their perceived usefulness and perceived ease of use, enhance their self-efficacy, lessen their computer anxiety and strengthen their positive attitudes towards technology through providing short and long-term professional and attitudinal development and training programs associated with educational technology. In addition, Saudi higher education institutions could provide technology support services that would help lessen computer anxiety by for example setting up interactive help desk and group discussions. There could also be some orientation lectures on how to use academic systems such as the LMS and online database. It is also of great importance that the university IT investment be promoted in such a way that easy-to-use, usable, simple and efficient educational systems are designed. 


\section{Limitations of the study and directions for future research}

Several areas for future investigation and research are identified here. There is no claim in this paper that the internal factors presented and tested here are exhaustive. More work is needed to investigate the influence of other internal and external factors on the adoption and integration of ICT by the teaching staff at Hail University. At the same time, the study population was very limited consisting only of the teaching staff at Hail University. Other users (students and administrators) might have a different opinion. The internal factors tested in this study could also be examined with Hail University students and/ or administrators as the study population. This could help check whether the same findings could be obtained and thus generalized. On the other hand, as this study has been conducted in a small university, compared with the other larger Saudi universities and in a single location, Hail University, it seems thus that more studies are required in a more and larger Saudi educational settings and institutions to validate the findings and results of this study.

The factors under focus/ examined in this study needs to tested in a further and broader Saudi context, in the other Saudi universities for example to come to a more comprehensive understanding of the ICT in the higher education in the KSA and to check the possibility to generalize the findings of this study.

\section{Conclusion}

The use of technology in higher education in the developing countries particularly in the KSA, though remains a challenge, has become an integral and indispensable part of the educational and academic activities particularly amid the COVID-19 pandemic at present. The interactive model developed in this study has been able to identify successfully the userrelated factors that would make the use of technology more efficient, more widespread and more frequent in Saudi higher education institutions now and in the period after the pandemic. Using SmartPLS program, the proposed model has been empirically validated. All the study six hypotheses have been supported. The relationship among these hypotheses are clear and significant. Data analysis of this study have shown that perceived usefulness, perceived ease of use, computer self-efficacy, attitudes and computer anxiety have direct and substantial effect on the university teaching staff's intention to use technology. Additionally, behavioral intention has a positive and significant effect on the successful use of technology.

Moreover, it should be noted that the study results are clearly consistent with the previous findings in the literature of technology adoption and integration, particularly those confirmed by TAM, UTAUT and TAM3 theories and models. This study should be viewed thus as a significant progress and remarkable continuity of these theories with the regard to explaining the factors influencing the integration and adoption of technology in higher education.

\section{Acknowledgments}

This research has been funded by Scientific Research Deanship at University of Ha'il - Saudi Arabia through project number. RG-20 107.

\section{Author contributions}

CONCEPTION: Fawaz Jazim, Abdullah Mohammed Al-Ghurbani and Yaser Hasan S. Al-Mamary METHODOLOGY: Mohammed Abdulrab and Yaser Hasan S. Al-Mamary

DATA COLLECTION: Fawaz Jazim, Mohammed Abdulrab and Imran Khan

INTERPRETATION OR ANALYSIS OF DATA: Yaser Hasan S. Al-Mamary and Mohammed Abdulrab

PREPARATION OF THE MANUSCRIPT: Fawaz Jazim, Abdullah Mohammed Al-Ghurbani and Imran Khan REVISION FOR IMPORTANT INTELLECTUAL CONTENT: Mohammed Abdulrab, Abdullah Mohammed Al-Ghurbani and Imran Khan SUPERVISION: Yaser Hasan S. Al-Mamary and Fawaz Jazim

\section{References}

[1] Lazar S. The importance of educational technology in teaching. International Journal of Cognitive Research in Science. Engineering and Education. 2015;3(1).

[2] Orey M. Emerging perspectives on learning, teaching and technology. 2010: CreateSpace North Charleston.

[3] Pajo K, Wallace C. Barriers to the uptake of web-based technology by university teachers. Journal of Distance Education. 2001;16(1):70-84. 
[4] Volman M, van Eck E. Gender equity and information technology in education: The second decade. Review of Educational Research. 2001;71(4):613-34.

[5] Viane I, et al. Acceptance of pain is an independent predictor of mental well-being in patients with chronic pain: empirical evidence and reappraisal. Pain. 2003;106(12):65-72.

[6] Sarkar S. The role of information and communication technology (ICT) in higher education for the 21 st century. Science. 2012;1(1):30-41.

[7] Jabli N, Qahmash A. The benefits and barriers of elearning in higher education in Saudi Arabia. 2013.

[8] Guillén-Gámez FD, Mayorga-Fernández MJ. Identification of variables that predict teachers' attitudes toward ICT in higher education for teaching and research: A study with regression. Sustainability. 2020;12(4):1312.

[9] Al-Mamary YHS. The impact of transformational leadership on organizational citizenship behaviour: Evidence from Malaysian higher education context. Human Systems Management. 2021(Preprint): p. 1-13.

[10] AL-Arfaj AH. The perception of college students in Saudi Arabia towards distance web-based instruction. 2001: Ohio University.

[11] Kincannon JM. From the classroom to the Web: A study of faculty change. 2000.

[12] Al Mulhim E. The Barriers to the Use of ICT in Teaching in Saudi Arabia: A Review of Literature. Universal Journal of Educational Research. 2014;2(6):487-93.

[13] Hirumi A. Does the use of technology improve learning? The answer lies in design. STEM (Science Technology Engineering Math), 2014: pp. 8.

[14] Jeng Y-L, et al. The add-on impact of mobile applications in learning strategies: A review study. Journal of Educational Technology \& Society. 2010;13(3):3-11.

[15] Meda L, Makura AH. Technology driven curriculum for 21st century higher education students in Africa. 2017: Langaa RPCIG.

[16] Alwan YHS. Development of an Integrated Model for Adoption of Management Information Systems in Yemeni Telecommunication Organizations. 2016, Universiti Tun Hussein Onn Malaysia.

[17] Bala H, et al. How Does an Enterprise System Implementation Change Interpersonal Relationships in Organizations. Bala, H., Venkatesh, V., Ganster, DC and Rai, A., How Does an Enterprise System Implementation Change Interpersonal Relationships in Organizations. Industrial Management \& Data Systems, Forthcoming, 2020.

[18] Osika J, et al. Analysis of material deformation during the new cold tube rolling process realized on the new generation of pilger mills. Archive of Metallurgy and Materials. 2009;54(4):1239-51.

[19] Asiri S, et al. Incidence rates of breast cancer by age and tumor characteristics among Saudi women: recent trends. Cureus. 2020;12(1)

[20] Stephens JC, et al. Higher education as a change agent for sustainability in different cultures and contexts. International Journal of Sustainability in Higher Education, 2008.

[21] van Braak J. Factors influencing the use of computer mediated communication by teachers in secondary schools. Computers \& Education. 2001;36(1):41-57.
[22] Al-Zaidiyeen N, Mei L, Fook F. In-service teachers' attitudes towards the use of information and communication technology in teaching practice: the case of Jordan. in Conference IMETC2008 Kuantan Malaysia. 2008.

[23] Chuntao D. A study on factors of influencing faculty use of modern instructional technology in higher education. in IEEE Int. Conf. 2010.

[24] Gleadow R, et al. New tools for a new age: An evolution or revolution in higher education? F1000Research, 2015; 4.

[25] Gammill TD. Factors associated with faculty use of webbased instruction in higher education. 2004: Mississippi State University.

[26] Tusubira F, Mulira N. Integration of ICT in Higher Education Institutions: Challenges and best practice recommendations based on experience of Makerere University \& Other organisations. Makerere University, 2005.

[27] Peeraer J, Van Petegem P. Factors influencing integration of ICT in higher education in Vietnam. in Global Learn. 2010. Association for the Advancement of Computing in Education (AACE)

[28] Lopes CT. Evaluating e-learning readiness in a health sciences higher education institution. in IADIS International Conference ELearning. 2007. Citeseer.

[29] Mostert M, Quinn L. Using ICTs in teaching and learning: Reflections on professional development of academic staff. International Journal of Education and Development using ICT. 2009;5(5):72-84.

[30] Neeru S. ICT in Indian Universities and Colleges. Management and Change. 2009;13(2).

[31] Shabaya P. The changing role of information and communication technologies (ICTs) for instruction in higher education institutions in Kenya. 2009.

[32] Qudais MA, Al-Adhaileh M, Al-Omari A. Senior Faculty Members' Attitudes in Jordanian Universities towards Using Information and Communication Technology. Int Arab J e Technol. 2010;1(4):135-41.

[33] Nawaz, A, Kundi GM. Demographic implications for the user-perceptions of E-learning in higher education institutions of N-WFP, Pakistan. The Electronic Journal of Information Systems in Developing Countries. 2010;41(1):1-17.

[34] Vajargah KF, Jahani S, Azadmanesh N. Application of ICTS in Teaching and Learning at University Level: The Case of Shahid Beheshti University. Turkish Online Journal of Educational Technology-TOJET. 2010;9(2): 33-9.

[35] Shi H. Developing e-learning materials for software development course. arXiv preprint arXiv:1006.0878, 2010.

[36] Said EH. ICT use by journalism professors in Colombia. Australasian Journal of Educational Technology. 2011;27(2).

[37] Agbo IS. Factors influencing the use of information and communication technology (ICT) in teaching and learning computer studies in Ohaukwu local government area of Ebonyi state-Nigeria. Journal of Education and Practice. 2015;6(7):71-86.

[38] De Freitas S, Conole G. The influence of pervasive and integrative tools on learners' experiences and expectations of study. Rethinking learning for a digital age: How learners are shaping their own experiences. 2010: pp. 15-30. 
[39] Wee M-C, Zaitun AB. Obstacles Towards the Use of ICT Tools in Teaching and Learning of Information Systems in Malaysian Universities. Int Arab J Inf Technol. 2006;3(3):203-9.

[40] Balanskat A, Blamire R, Kefala S. The ICT impact report. European Schoolnet. 2006;1:1-71.

[41] Richardson JW. Challenges of adopting the use of technology in less developed countries: The case of Cambodia. Comparative Education Review. 2011;55(1):008-029.

[42] Alonso RR, Plaza IR, Orfali CH. Barriers in teacher perception about the use of technology for evaluation in Higher Education. Digital Education Review. 2019(35):170-85.

[43] Alenezi A. Barriers to participation in learning management systems in Saudi Arabian universities. Education Research International. 2018; 2018.

[44] Linzalone R, Schiuma G, Ammirato S. Connecting universities with entrepreneurship through digital learning platform: functional requirements and education-based knowledge exchange activities. International Journal of Entrepreneurial Behavior \& Research. 2020.

[45] Alharbi O, et al. The issues and advantages of the use of new technology in Saudi education: A literature review. Advances in Social Sciences Research Journal. 2019;6(8).

[46] Al-Maliki S, Mohammed A. The investment opportunities for building smartphone applications for tourist cities in Saudi Arabia. Expert Systems in Finance: Smart Financial Applications in Big Data Environments. 2019;112.

[47] Alkhalaf S, et al. E-learning system on higher education institutions in KSA: Attitudes and perceptions of faculty members. Procedia-Social and Behavioral Sciences. 2012;47:1199-205.

[48] Basri WS, Alandejani JA, Almadani FM. ICT adoption impact on students' academic performance: Evidence from Saudi universities. Education Research International. 2018; 2018.

[49] Zhao Y, et al. Conditions for classroom technology innovations. Teachers College Record. 2002;104(3): 482-515.

[50] Balash F, Yong Z, Bin Abu B. Lecturers and educational technology: Factors affecting educational technology adoption in teaching. in 2nd International Conference on Education and Management Technology IPCSIT. 2011.

[51] Betts KS. Factors influencing faculty participation in distance education in postsecondary education in the United States: An institutional study. 1998: The George Washington University.

[52] Almalki G, Williams N. A strategy to improve the usage of ICT in the Kingdom of Saudi Arabia primary school. International Journal of Advanced Computer Science \& Application. 2012;3.

[53] Sang G, et al. Student teachers' thinking processes and ICT integration: Predictors of prospective teaching behaviors with educational technology. Computers \& Education. 2010;54(1):103-12.

[54] Davis FD, Bagozzi RP, Warshaw PR. User acceptance of computer technology: A comparison of two theoretical models. Management Science. 1989;35(8):982-1003.

[55] Davis FD. Perceived usefulness, perceived ease of use, and user acceptance of information technology. MIS Quarterly. 1989: pp. 319-340.
[56] Venkatesh V, et al. User acceptance of information technology: Toward a unified view. MIS quarterly. 2003: pp. 425-478.

[57] Teo T, Lee CB, Chai CS. Understanding pre-service teachers' computer attitudes: applying and extending the technology acceptance model. Journal of Computer Assisted Learning. 2008;24(2):128-43.

[58] Jeung H. Understanding teachers' continuance intentions towards distance training program: An Extension of technology acceptance model. Journal of Lifelong Learning Society. 2014;10(2):229-62.

[59] Lu X, Viehland D. Factors influencing the adoption of mobile learning. 2008.

[60] Joo YJ, Park S, Lim E. Factors influencing preservice teachers' intention to use technology: TPACK, teacher self-efficacy, and technology acceptance model. Journal of Educational Technology \& Society. 2018;21(3):48-59.

[61] Al-Khaldi MA, Al-Jabri IM. The relationship of attitudes to computer utilization: New evidence from a developing nation. Computers in Human Behavior. 1998;14(1):23-42.

[62] Alshmrany S, Wilkinson B. Factors influencing the adoption of ICT by teachers in primary schools in Saudi Arabia. International Journal of Advanced Computer Science and Applications. 2017;8(12):143-56.

[63] Thompson RL, Higgins CA, Howell JM. Personal computing: Toward a conceptual model of utilization. MIS quarterly. 1991: pp. 125-143.

[64] Chin WW, Gopal A. Adoption intention in GSS: Relative importance of beliefs. ACM SIGMIS Database: the DATABASE for Advances in Information Systems. 1995;26(2-3):42-64.

[65] Gibson JL, Ivancevich JM, Donnelly J. Organizations: Behavior, Structure, Processes, Homewood, I1.: Richard D. Irwin. 1991, Inc.

[66] Triandis HC, Malpass RS, Davidson AR. Cross-cultural psychology. Biennial Review of Anthropology. 1971;7: 1-84.

[67] Rogers EM, Singhal A, Quinlan MM. Diffusion of innovations. 2014: Routledge.

[68] Watson DM. Blame the technocentric artefact! What research tells us about problems inhibiting teacher use of IT, in Capacity building for IT in education in developing countries. 1998, Springer. pp. 185-192.

[69] Isleem MI. Relationships of selected factors and the level of computer use for instructional purposes by technology education teachers in Ohio public schools: a statewide survey. 2003, The Ohio State University.

[70] Albirini A. Teachers' attitudes toward information and communication technologies: The case of Syrian EFL teachers. Computers \& Education. 2006;47(4):373-98.

[71] MacCallum K. Attitudes of educators to the introduction of mobile technology, in the 1st annual conference of Computing and Information Technology Research and Education 2010: Dunedin, New Zealand.

[72] Mac Callum K, Jeffrey L. Factors impacting teachers' adoption of mobile learning. Journal of Information Technology Education, 2014; 13.

[73] Attwell G. What is the significance of Open Source Software for the education and training community. in The First International Conference on Open Source Systems (OSS 2005), Genova, Italy, July 11. 2005. 
[74] Inan FA, Lowther DL. Factors affecting technology integration in K-12 classrooms: A path model. Educational Technology Research and Development. 2010;58(2): 137-54.

[75] Bandura A. Exercise of personal and collective efficacy in changing societies. Self-Efficacy in Changing Societies. 1995;15:334.

[76] Thatcher JB, Perrewe PL. An empirical examination of individual traits as antecedents to computer anxiety and computer self-efficacy. MIS quarterly, 2002: pp. 381-396.

[77] Celik V, Yesilyurt E. Attitudes to technology, perceived computer self-efficacy and computer anxiety as predictors of computer supported education. Computers \& Education. 2013;60(1):148-58.

[78] Albion PR. Self-efficacy beliefs as an indicator of teachers' preparedness for teaching with technology. in Society for Information Technology \& Teacher Education International Conference. 1999. Association for the Advancement of Computing in Education (AACE).

[79] Anderson SE, Groulx JG, Maninger RM. Relationships among preservice teachers' technology-related abilities, beliefs, and intentions to use technology in their future classrooms. Journal of Educational Computing Research. 2011;45(3):321-38.

[80] Valtonen T, et al. The impact of authentic learning experiences with ICT on pre-service teachers' intentions to use ICT for teaching and learning. Computers \& Education. 2015;81:49-58.

[81] Ball DM, Levy Y. Emerging educational technology: Assessing the factors that influence instructors' acceptance in information systems and other classrooms. Journal of Information Systems Education. 2008;19(4):431.

[82] Newhouse JP. Why is there a quality chasm? Health affairs. 2002;21(4):13-25.

[83] Snoeyink R, Ertmer PA. Thrust into technology: How veteran teachers respond. Journal of Educational Technology Systems. 2001;30(1):85-111.

[84] Williams D, et al. Teachers and ICT: Current use and future needs. British Journal of Educational Technology. 2000;31(4):307-20.

[85] Agarwal R, Karahanna E. Time flies when you're having fun: Cognitive absorption and beliefs about information technology usage. MIS quarterly. 2000: pp. 665-694.

[86] Korukonda AR. Differences that do matter: A dialectic analysis of individual characteristics and personality dimensions contributing to computer anxiety. Computers in Human Behavior. 2007;23(4):1921-42.

[87] Harrington KV, McElroy JC, Morrow PC. Computer anxiety and computer-based training: A laboratory experiment. Journal of Educational Computing Research. 1990;6(3):343-58.

[88] Arigbabu AA. Examining psychometric characteristics of the computer anxiety scale. Computers in Human Behavior. 2009;25(1):229-32.

[89] Jahromi SAF, Forouzan A, Gholaminejad R. Computer anxiety and computer self-efficacy as predictors of Iranian EFL learners' performance on the reading section of the TOEFL iBT. Higher Education of Social Science. 2016;11(6):55-65.

[90] Jain A. Computer in education. 2005: Gyan Publishing House.
[91] Awofala AO, et al. Attitudes toward Computer, Computer Anxiety and Gender as Determinants of Pre-Service Science, Technology, and Mathematics Teachers' Computer Self-Efficacy. Digital Education Review. 2019;36:51-67.

[92] Yakubu MN, Dasuki S. Assessing eLearning systems success in Nigeria: An application of the DeLone and McLean information systems success model. Journal of Information Technology Education: Research. 2018;17: 183-203.

[93] Ngai EW, Poon J, Chan YH. Empirical examination of the adoption of WebCT using TAM. Computers \& Education. 2007;48(2):250-67.

[94] Aljazzaf Z. Factors influencing the use of multimedia technologies in teaching English language in Kuwait. International Journal of Emerging Technologies in Learning (IJET). 2020;15(5):212-34.

[95] Tarhini A, Hone K, Liu X. Factors affecting students' acceptance of e-learning environments in developing countries: a structural equation modeling approach. 2013.

[96] Dillman DA, Smyth JD, Christian LM. Internet, phone, mail, and mixed-mode surveys: the tailored design method. 2014: John Wiley \& Sons.

[97] Fricker RD. Sampling methods for online surveys. The SAGE handbook of online research methods. 2016;12(3):184-202.

[98] Hair Jr JF, et al. A primer on partial least squares structural equation modeling (PLS-SEM). 2016: Sage publications.

[99] Abdulrab M, et al. The Impact of Transformational Leadership and Psychological Empowerment on Organizational Citizenship Behaviors: A PLS-SEM Approach. Journal of Critical Reviews. 2020;7(9):908-17.

[100] Al-Mamary YHS, et al. Development of an Integrated Model For Successful Adoption of Management Information Systems In Yemeni Telecommunication Organizations. International Journal of Scientific \& Technology Research. 2019;8(11):3912-39.

[101] Abdulrab M, et al. Mediating role of strategic orientations in the relationship between entrepreneurial orientation and performance of Saudi SMEs. Brazilian Journal of Operations \& Production Management. 2021;18(4):1-15.

[102] Al-Tahitah AN, Al-Sharafi MA, Abdulrab M. How COVID-19 Pandemic Is Accelerating the Transformation of Higher Education Institutes: A Health Belief Model View. Emerging Technologies During the Era of COVID19 Pandemic. 2021;348:333.

[103] Al-Mamary YHS. Using Structural Equation Modeling Approach to Investigate the Impact of Technological Factors on User Satisfaction. Calitatea. 2020;21(178):90-95.

[104] Al-Mamary YHS. Examining the factors affecting the use of ICT in teaching in Yemeni schools. Journal of Public Affairs: pp. e2330.

[105] Abdulrab M. Factors Affecting Acceptance and the Use of Technology in Yemeni Telecom Companies. International Transaction Journal of Engineering, Management, \& Applied Sciences \& Technologies. 2020;11(6):1-16.

[106] Nunnally JC. Psychometric theory 3E. 1994: Tata McGraw-hill education.

[107] Henseler J, Ringle CM, Sarstedt M. A new criterion for assessing discriminant validity in variance-based structural equation modeling. Journal of the Academy of Marketing Science. 2015;43(1):115-35. 
[108] Cohen J. Statistical power analysis for the behavioral sciences. Hilsdale. NJ: Lawrence Earlbaum Associates. 1988, New York: Lawrence Erlbaum Associates, Publishers. 23.

[109] Kim Y. et al. Factors Associated with Poor Quality of Sleep in Construction Workers: A Secondary Data Analysis. International Journal of Environmental Research and Public Health. 2021;18(5):2279.

[110] Hamid AA, et al. The effects of perceived usefulness and perceived ease of use on continuance intention to use e-government. Procedia Economics and Finance. 2016;35:644-9.

[111] Hussain A, Mkpojiogu EO, Yusof MM. Perceived usefulness, perceived ease of use, and perceived enjoyment as drivers for the user acceptance of interactive mobile maps. in AIP Conference Proceedings. 2016. AIP Publishing LLC.

[112] Smarkola C. Technology acceptance predictors among student teachers and experienced classroom teachers. Journal of Educational Computing Research. 2007;37(1):6582.

[113] Adams DA, Nelson RR, Todd PA. Perceived usefulness, ease of use, and usage of information technology: A replication. MIS quarterly. 1992: pp. 227-247.

[114] Hendrickson AR, Massey PD, Cronan TP. On the testretest reliability of perceived usefulness and perceived ease of use scales. MIS quarterly, 1993: pp. 227-230.

[115] Jebeile S, Reeve R. The diffusion of e-learning innovations in an Australian secondary college: Strategies and tactics for educational leaders. Innovation. 2003;8(4).
[116] Liu Z, Yuan W, Ma Y. Drivers' Attention Strategies before Eyes-off-Road in Different Traffic Scenarios: Adaptation and Anticipation. International Journal of Environmental Research and Public Health. 2021;18(7):3716.

[117] Hu PJ-H, Clark TH, Ma WW. Examining technology acceptance by school teachers: a longitudinal study. Information \& Management. 2003;41(2):227-41.

[118] Agarwal R, Prasad J. Are individual differences germane to the acceptance of new information technologies? Decision Sciences. 1999;30(2):361-91.

[119] Banas JR, York CS. Authentic learning exercises as a means to influence preservice teachers' technology integration self-efficacy and intentions to integrate technology. Australasian Journal of Educational Technology. 2014;30(6).

[120] Cambre MA, Cook DL. Computer anxiety: Definition, measurement, and correlates. Journal of Educational Computing Research. 1985;1(1):37-54.

[121] Hackbarth G, Grover V, Mun YY. Computer playfulness and anxiety: positive and negative mediators of the system experience effect on perceived ease of use. Information \& Management. 2003;40(3):221-32.

[122] Igbaria M, Iivari J. The effects of self-efficacy on computer usage. Omega. 1995;23(6):587-605.

[123] Saadé RG, Kira D. The emotional state of technology acceptance. Issues in Informing Science \& Information Technology. 2006;3. 